\title{
Silicon fertilization reduces the deleterious effects of water deficit in sugarcane
}

\author{
Camargo M.S. de ${ }^{1 *}$, B.K.L. Bezerra ${ }^{2}$, A.C.Vitti ${ }^{1}$, M.A. Silva ${ }^{2}$, Oliveira, A.L. ${ }^{3}$
}

${ }^{1}$ PRDTA Centro Sul, Agência Paulista de Tecnologia dos Agronegócios (APTA), 13412-050, Piracicaba, Brazil. '2College of Agricultural Sciences, Department of Crop Production, São Paulo State University (UNESP), 18603-970, Botucatu, Brazil. ${ }^{3}$ Centro de Ciências Agrárias, Universidade Federal de São Carlos, 13604-900, Araras, Brazil. "Corresponding author: mscamarg@yahoo.com.br

\begin{abstract}
Few studies have focused on water deficit for sugarcane, whose damage could be reduced with $\mathrm{Si}$, as shown in other crops. This study aimed to determine whether Si fertilization enhances the best recovery of sugarcane after two periods of the formative phase (tillering and early grand growth) for RB86-7515 (drought tolerant) and RB85-5536 (drought sensitive), and which growth phase is beneficial for each cultivar. It was investigated: 1) the effect of Si fertilization on total Si uptake, and on soluble Si in soil; 2) whether Si uptake could provided increased stalk yield, juice quality, dry biomass compared to well-watered treatments. Two experiments were conducted in pots under greenhouse: one with RB86-7515 and another with RB85-5536. Treatments were: 1-Non-Deficit+Si, 2-Non-Deficit-Si, 3-Early Deficit (ED)+Si, 4-ED-Si, 5-Late Deficit (LD)+Si, and 6-LD-Si. Silicon fertilization provided best recovery of sugarcane (superior sugar, stalk yield, and dry biomass) after early and late water deficit compared to its absence for both cultivars. For RB85-5536, Si fertilization propitiated similar recovery for water deficit and continuous irrigation treatments. No differences were observed between periods of water deficit. Therefore, Si fertilization at planting should be considered another tool for reducing the damage caused by water deficit in sugarcane.
\end{abstract}

Keywords: Silicate, soil fertility, fertilization, nutrition, drought 


\section{Introduction}

Water deficit is one of the major factors limiting crop production, especially due to global warming and climate change, resulting in extensive drought periods during critical growth stages (Ramesh, 2000). Sugarcane (Saccharum officinarum L.), which is the main crop for worldwide sugar production and bioenergy production, is strongly influenced by the water deficit. This crop is cultivated in several types of soils, including sandy and sandy loam soils sandy soils with low water-storage capacity that are subjected to drought (Boaretto et al., 2014). Negative impacts of water deficit have already been reported on the sugar and stalk yield (Ramesh, 2000; Silva et al., 2008; Oliveira et al., 2011; Boaretto et al., 2014). Water requirement for sugarcane is variable in function of growth stages (germination, tillering, grand growth and maturation) and cultivar (Ramesh, 2000). Water deficit during the formative phase of sugarcane, which includes the tillering phase and the early grand growth period, reduces significantly stalk yield and sugar production (Ramesh, 2000; Silva and Costa, 2004). Brazil is a major worldwide sugarcane producer, with a total production of 658 million tons from 9.0 million hectares during the 2015/16 growing season (Conab, 2016). In the South Central region of Brazil, which has the largest area and yield, drought periods generally occur from May to August and are characterized by low rain, low temperatures and few hours of sunlight, coinciding with the formative phase for sugarcane planted from January to April. Increased stalk yield can be obtained with irrigation during this drought period (Gava et al., 2011) but is still costly, making it important to choose a formative phase period (tillering or early grand growth) for water application. Moreover, it is essential to choose a drought tolerant cultivar for the given conditions.
Several studies have already conducted to compare sugarcane cultivars under well-watered and water deficit conditions in pots (Machado et al., 2009; Carlin and Santos, 2009; Pincelli and Silva, 2012; Abbas et al., 2014) and the field (Gava et al,. 2011; Boaretto et al., 2014) in order to identify drought-tolerant cultivars to be planted in soils that are prone to water deficit. Despite some drought-tolerant cultivars having been identified, some sensitive cultivars are still being used under field conditions due to a superior sugar yield, even with a low stalk yield, which cannot be found in several drought-tolerant cultivars. In addition these studies have not shown the effects of the recovery of plants at harvest if water is supplied after these stressful conditions, which commonly occur under field conditions, as performed by Machado et al., (2009). These authors have reported strong effects on recovery of dry biomass after severe water deficit (10-40\% field capacity). Although irrigation could be necessary to some soils prone to water deficit, it can be expensive and new management practices, such as silicon fertilization, must be studied to maintain or increase stalk and sugar yield in these conditions.

Silicon ( $\mathrm{Si}$ ) is second most common element in the Earth's crust and soil main constituent, but low $\mathrm{Si}$ soluble concentrations are found in soils with low clay contents, which are also prone to water deficit. Even though this element is not considered a nutrient (Epstein, 2009), some plants are considered Si-accumulation such as sugarcane and its uptake can reach up to 200-500 $\mathrm{kg} \mathrm{ha}^{-1} \mathrm{Si}$ in one harvest (Camargo et al., 2010). After Si is taken up by the roots as monosilicic acid $\left(\mathrm{H}_{4} \mathrm{SiO}_{4}\right)$, most of it is polymerized, forming a cuticle-silicon double-layer in epidermal cells, and less than 1\% remains soluble (Epstein, 2009). In sugarcane, Si uptake increases the photosynthetic capacity (Epstein, 2009) and stalk and sugar yield (Mc 
Cray and Ji, 2012; Keeping et al., 2013; Camargo et al., 2014) and reduces the damage inflicted by diseases (Camargo et al., 2013), insects (Keeping and Meyer, 2013; Camargo et al., 2014), and salinity (Ashraf et al., 2010).

Negatives effects of water deficit can be also reduced by $\mathrm{Si}$, as already reported in rice (Epstein, 2009), wheat (Gong et al., 2005), and sorghum (Hattori et al., 2005). The alleviation of the deleterious effects of water deficit with Si fertilization are related to an increased water use efficiency (Epstein, 2009), limiting the loss of water through transpiration (Hattori et al., 2005), reduced oxidative damage (Gong et al., 2005), electrolyte leakage, and increased photosynthetic activity (Gong et al., 2005; Hattori et al., 2005) and biomass yield (Eneji et al., 2008). However, association between water deficit and Si fertilization in sugarcane was not studied yet, with the exception of Oliveira et al., (2010). These authors reported a 34\% increase in the dry biomass of sugarcane growing in pots under moderate water stress when silicate was applied to the soil compared to the control (without Si, $100 \%$ field capacity).

This study aimed to determine whether Si fertilization enhances the best recovery of sugarcane after two periods of the formative phase (tillering and early grand growth) for RB86-7515 (drought tolerant) and RB85-5536 (drought sensitive), and which growth phase is beneficial, and how Si may contribute to reduce the damage of drought for each cultivar. So it was investigated: 1) the effect of $\mathrm{Si}$ fertilization on total Si uptake, and on soluble Si in soil; 2) whether Si uptake could provided increased stalk yield, juice quality, dry biomass of two sugarcane cultivars compared to well-watered treatments. Both sugarcane cultivars are widely planted in Brazil. Water deficit was imposed by establishing $55 \%$ of field capacity of soil, simulating conditions of moderate deficit.

\section{Material and Methods}

\subsection{Plant materials}

Sugarcane cultivars were also chosen due to their major participation in the cultivated area of sugarcane in Brazil. The drought-tolerant sugarcane cultivar RB86-7515 (Pincelli and Silva, 2012; Gentile et al., 2013) is the principal sugarcane cultivar, and RB855536, drought-sensitive (Gentile et al., 2013) it is the 7 th most cultivated cultivar in Brazil, even though it is considered drought sensitive according to the cultivar data from Ridesa (2011).

\subsection{Experimental procedure}

Two experiments with sugarcane grown in pots (polyethylene water tanks, $100 \mathrm{~L}$ ) in a greenhouse at an experimental farm in Piracicaba (22 42" $30^{\circ}$ S; 47 o 38 " 01' W), SP, Brazil, were conducted between October 2013 and December 2014. The minimum and maximum temperatures and the relative humidity of air were monitored daily (Figure 1).

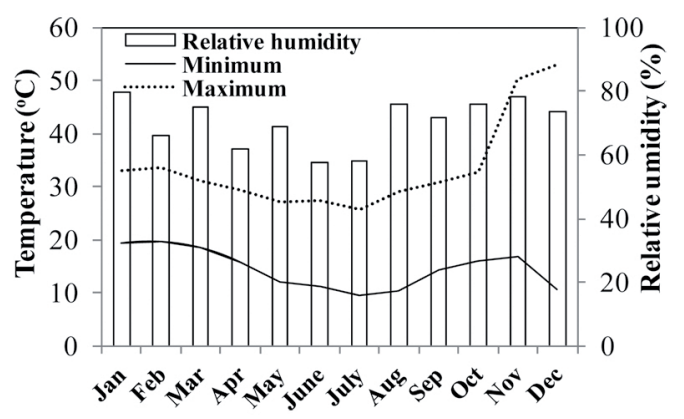

Figure 1. Maximum and minimum temperature and relative umidity during experiments conducted under greenhouse conditions of two sugarcane cultivars. 
A Typic Quartzipsamment soil (93\% sandy) with a low soluble $\mathrm{Si}$ concentration $\left(0.9 \mathrm{mg} \mathrm{kg}^{-1} \mathrm{Si}\right.$ extracted by $0.01 \mathrm{~mol} \mathrm{~L}^{-1} \mathrm{CaCl}_{2}$ ) was used to fill the pots due to positive effect on Si fertilization, according to Berthelsen et al., (2001) and others (Camargo et al., 2013, 2014). The soil chemical characteristics showed $\mathrm{pHCaCl}_{2}=4.8$; organic matter $=2 \mathrm{~g} \mathrm{~kg}^{-1}$; $\mathrm{P}$ resin $=3.0 \mathrm{mg} \mathrm{dm}^{-3} ; \mathrm{K}, \mathrm{Ca}$, and $\mathrm{Mg}=0.5,9$, and 2 mmolc $\mathrm{dm}^{-3}$, respectively; cation exchangeable capacity $(\mathrm{CEC})=21.8$; basis saturation $(\mathrm{SB})=49 \%$; and aluminum saturation $=1 \%$.

A completely randomized design with six treatments and four replications was used in two experiments. One experiment was performed with the drought-tolerant (RB86-7515), and another was conducted with the drought-sensitive (RB85-5536). Treatments were: 1-ND+Si (Non-deficit and $600 \mathrm{~kg} \mathrm{ha}^{-1} \mathrm{Si}$ ), 2-ND-Si (Non-deficit-Si and no Si applied), 3-ED+Si (Early Deficit and $600 \mathrm{~kg} \mathrm{ha}^{-1} \mathrm{Si}$ at 4 months), 4-ED-Si (Early Deficit and no Si applied at 4 months), 5-LD+Si (Late Deficit and $600 \mathrm{~kg} \mathrm{ha}^{-1} \mathrm{Si}$ at 6 months), and 6-LD-Si (Late Deficit and $\mathrm{n} \mathrm{Si}$ applied at 6 months). The soil moisture was kept close to $100 \%$ field capacity for ND treatments. Water deficit (ED, LD) was imposed by establishing $55 \%$ of field capacity of soil, simulating conditions of moderate deficit given at the tillering phase (ED, 4 months) and the early grand growth period (LD, 6 months) for 60 days for each stress. All of the treatments were adjusted to receive the same quantities of $\mathrm{Ca}$ and $\mathrm{Mg}$. Ca-Mg silicate $\left(274 \mathrm{~g} \mathrm{~kg}^{-1} \mathrm{Ca} ; 481 \mathrm{~g} \mathrm{~kg}^{-1}\right.$ $\mathrm{Mg}$ and $108.4 \mathrm{~g} \mathrm{~kg}^{-1} \mathrm{Si}$ ) was used in treatments with $\mathrm{Si}$ (+Si) and lime (343 $\mathrm{g} \mathrm{kg}^{-1} \mathrm{Ca}$ and $\left.96 \mathrm{~g} \mathrm{~kg}^{-1} \mathrm{Mg}\right)$, and $\mathrm{MgCl}_{2}(11.9 \% \mathrm{Mg})$ was used in those without $\mathrm{Si}(-\mathrm{Si})$. Soil was collected from areas of native vegetation, airdried for 20 days, and sifted through a 5-mm screen before being used to fill the pots. The treatment materials (silicate, lime and/or $\mathrm{MgCl}_{2}$ ) were applied in the upper $10 \mathrm{~cm}$, and the soil was homogenized inside plastic bags. After treatment application (October 15, 2013), the pots were incubated for 11 weeks to provide soil chemical reactions.

Transplants were produced from single-budded setts cut from stalks of each cultivar collected from a commercial field. Sugarcane setts were planted on December 11, 2013, in plastic pots containing sandy soil in order to provide similar plants regarding height and root system. Two sugarcane plants with heights between 100 and $130 \mathrm{~mm}$ in the same phenological stage (early growth) were transplanted into each pot in January 2014. The soil was fertilized with nitrogen, phosphorus and potassium based on the soil analyses (Raij et al., 1997). Basal fertilization was performed with $180 \mathrm{~kg} \mathrm{ha}^{-1} \mathrm{P}_{2} \mathrm{O}_{5}$ (simple superphosphate), $30 \mathrm{~kg} \mathrm{ha}^{-1}$ $\mathrm{N}$ (ammonium sulfate), and $100 \mathrm{~kg} \mathrm{ha}^{-1} \mathrm{~K}_{2} \mathrm{O}(\mathrm{KCl})$. Then, 30 days after planting, superficial fertilization was performed using $30 \mathrm{~kg} \mathrm{ha}^{-1} \mathrm{~N}$ and $100 \mathrm{~kg} \mathrm{ha}^{-1} \mathrm{~K}_{2} \mathrm{O}$. Each pot received $50 \mathrm{~mL}$ of a solution of $1000 \mathrm{~mL}$ of water plus $1 \mathrm{~mL}$ of Hoagland and Arnon's solution, containing the following quantities of each micronutrient $\left(\mathrm{g} \mathrm{L}^{-1}\right)$ : 1.81 of $\mathrm{H}_{3} \mathrm{BO} 3,2.86$ of $\mathrm{MnCl}_{2} \cdot 4 \mathrm{H}_{2} \mathrm{O}, 0.10$ of $\mathrm{ZnCl}_{2}, 0.04$ of $\mathrm{CuCl}_{2}$, and 0.02 of $\mathrm{H}_{2} \mathrm{MoO}_{4} \cdot \mathrm{H}_{2} \mathrm{O}$. The application of $50 \mathrm{~mL}$ in each pot was repeated every month until 6 months after transplanting.

Irrigation was carried out based on the soil moisture data obtained from the readings of puncture tensiometers installed at two depths ( 0 to $11.5 \mathrm{~cm}$ and 11.5 to $23 \mathrm{~cm}$ ) in each pot, according to Barbosa et al., (2014). Irrigation was performed using drippers ( $2 \mathrm{~L}$ per hour) and controlling the flow rate with water shut-off valves. For ND treatments, plants received water to maintain the soil moisture close to $100 \%$ field capacity during the experiments. In addition, water deficit treatments imposed at ED (May, 2014) or LD (July, 2014) during 60 days, plants received the amount of water required to maintain 55\% field capacity. After this period for each treatment (ED or LD), the plants received the same quantities of water to maintain $100 \%$ field capacity until harvest (December 9, 2014). 


\subsection{Treatments evaluation}

The ability of sugarcane to recover after being subjected to water deficit imposed at two growth phases was evaluated using data from biometric traits (height, diameter and length of stalks, and stalk yield) and technological analyses of the juice of two principal stalks harvested at 11 months after transplanting. The plant height was measured from the base to the top most visible dewlap leaf (DinardoMiranda et al., 2010) and stalk diameter measurements were taken in the central part of each stalk. The length of the stalks, which are commonly used in the sugar industry, was also measured from the base until leaves. It was also evaluated the parameters contributing to the technological juice quality of stalk: brix (o), purity (\%), fiber (\%), and sugar content (g/pot), according Consecana (2006).

The ground aerial part of the plant was divided into leaves, stalk and straw, which were dried, weighed, and ground. The Si contents in the dry matter tissue of sugarcane were determined according to Elliot and Snyder (1991). The Si uptake was determined by multiplying the $\mathrm{Si}$ content by the dry matter weight. The linear regression between the Si uptake (leaves+stalks+straw) by sugarcane and the extracted soluble Si concentrations in two extracting solutions used the model $y=a+b^{*} x$.

After harvest, eight soil samples per pot were collected after each harvest for evaluate soil fertility $\left(\mathrm{pHCaCl}_{2} ; \mathrm{P}\right.$ by anionic resin; $\mathrm{K}, \mathrm{Ca}$ and $\mathrm{Mg}$ by ammonium acetate method; cation exchange capacity; and basis saturation), according Raij et al., (1997). It was also evaluated soluble $\mathrm{Si}$ concentrations via extraction with $0.5 \mathrm{~mol} \mathrm{~L}^{-1}$ acetic acid and $0.01 \mathrm{~mol}$ $\mathrm{L}^{-1} \mathrm{CaCl}_{2}$ (Korndörfer et al., 1999).

\subsection{Statistical analysis}

The data were subjected to an analysis of variance by the $\mathrm{F}$ test for each experiment (cultivar). The treatments were compared by Tukey's test $(p<0.05)$ for each cultivar. All of the analyses were performed using the Statistical Analysis System software (SAS ${ }^{\circledR}$, Cary, NC, USA).

\section{Results}

3.1.Biometric parameters contributing to yield: height, diameter and length of stalks

The treatments did not affect, according to Tukey's test $(p<0.05)$, the plant height or stalk length, which were $123.1 \mathrm{~cm}$ and $93.5 \mathrm{~cm}$ on average for droughttolerant RB86-7515 and 105.5 and $17.2 \mathrm{~cm}$ on average for drought-sensitive RB85-5536, respectively, at harvest (Table 1). Differences between treatments were only observed in the stalk diameter of the sensitive cultivar. The lowest values of this diameter were found in the treatments without $\mathrm{Si}$ application with early (ED-Si) and late (LD-Si) water deficits.

\subsection{Stalk yield, shoot dry biomass and juice quality of sugarcane cultivars}

The drought-tolerant cultivar showed a higher stalk yield (Figure 2a) for ND+Si, followed by ND-Si, which was different from that with water deficit treatments $(\mathrm{ED}+\mathrm{Si}$ and $\mathrm{LD}-\mathrm{Si})$. The absence of $\mathrm{Si}$ fertilization in the soil decreased by $36 \%$ the stalk yield of the tolerant cultivar for ED-Si and LD-Si compared to $\mathrm{ND}+\mathrm{Si}$ treatment.

Silicon fertilization also increased the stalk yield of the drought-sensitive cultivar (Figure 2b). 
Table 1. Plant height, diameter and length in two sugarcane cultivars grown in sandy soil with and without $\mathrm{Si}$ fertilization under non-deficit and early and late water deficit.

\begin{tabular}{lcccccc}
\hline Treatments & \multicolumn{3}{c}{ Tolerant (RB86-7515) } & \multicolumn{3}{c}{ Sensitive (RB85-5536) } \\
& Height & Diameter & Lengh & Height & Diameter & Lengh \\
\hline Non-Deficit $+\mathrm{Si}$ & $115.87^{\mathrm{a}}$ & $21.20 \mathrm{a}$ & $88.50 \mathrm{a}$ & $110.50 \mathrm{a}$ & $17.7 \mathrm{ab}$ & $81.6 \mathrm{a}$ \\
Non-Deficit $-\mathrm{Si}$ & $125.62 \mathrm{a}$ & $20.00 \mathrm{a}$ & $92.13 \mathrm{a}$ & $98.25 \mathrm{a}$ & $16.9 \mathrm{ab}$ & $74.2 \mathrm{a}$ \\
Early Deficit $+\mathrm{Si}$ & $129.87 \mathrm{a}$ & $18.00 \mathrm{a}$ & $94.00 \mathrm{a}$ & $112.13 \mathrm{a}$ & $17.0 \mathrm{ab}$ & $84.0 \mathrm{a}$ \\
Early Deficit $-\mathrm{Si}$ & $120.25 \mathrm{a}$ & $19.00 \mathrm{a}$ & $92.00 \mathrm{a}$ & $91.75 \mathrm{a}$ & $16.7 \mathrm{~b}$ & $64.1 \mathrm{a}$ \\
Late déficit $+\mathrm{Si}$ & $128.62 \mathrm{a}$ & $20.62 \mathrm{a}$ & $105.63 \mathrm{a}$ & $121.63 \mathrm{a}$ & $18.75 \mathrm{a}$ & $84.7 \mathrm{a}$ \\
Late déficit $-\mathrm{Si}$ & $118.25 \mathrm{a}$ & $19.25 \mathrm{a}$ & $88.50 \mathrm{a}$ & $98.88 \mathrm{a}$ & $16.2 \mathrm{~b}$ & $72.9 \mathrm{a}$ \\
MSD $^{(0,05)}$ & 31.48 & 4.17 & 34.55 & 32.18 & 1.9 & 28.43 \\
\hline
\end{tabular}

a Mean values followed by the same letter in each columm are not significantly different at $\mathrm{P} \leq 0.05$. * $\mathrm{MSD}=$ minimum significative difference.
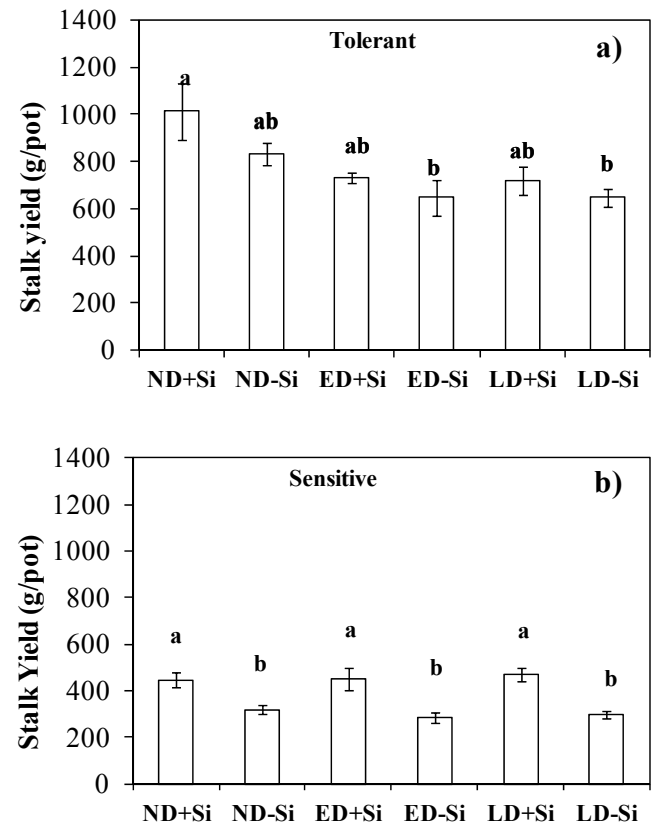

Figure 2. Stalk yield of drought-tolerant (a) and droughtsensitive (b) sugarcane cultivars grown in sandy soil with (+Si) and without $\mathrm{Si}(-\mathrm{Si})$ under non-deficit (ND), early (ED) and late water deficit (LD). Means followed by the same letter in the column do not differ by Tukey's test ( $p$ $<0.05$ ). MSD0.05=314.20 for the tolerance, and 106.90 for the sensitive. Standard error bars are included in all figures. $n=4$ repetitions.
However, there was no difference in the stalk yield among the treatments of water deficit with $\mathrm{Si}(\mathrm{ND}+\mathrm{Si})$ and water deficit $(\mathrm{ED}+\mathrm{Si}$ and $\mathrm{LD}-\mathrm{Si})$, unlike the tolerant cultivar. On the other hand, the lowest values were observed without $\mathrm{Si}$ application. Compared to that of the ND+Si treatment, ND-Si showed a $28 \%$ decrease in the stalk yield, even without water deficit, and a $36 \%$ decrease was observed for $\mathrm{ED}-\mathrm{Si}$ and $32 \%$ for $\mathrm{LD}-\mathrm{Si}$.

Different responses were observed in the aboveground dry biomass (leaves+stalk+straw) for each cultivar (Figure 3). The drought-tolerant cultivar showed higher values for $\mathrm{ND}+\mathrm{Si}$, and ND-Si compared to water deficit treatments, including in those treatments with Si application (Figure 3a).

On the other hand, a positive effect of Si fertilization was evident, alleviating the effects of water deficit on the total dry biomass of the sensitive cultivar (even with lower values than in the tolerant cultivar). Similar values of total dry matter were found for $\mathrm{ED}+\mathrm{Si}$ and $\mathrm{ND}+\mathrm{Si}$ (Figure $3 \mathrm{~b}$ ). No differences in the parameters contributing to the technological juice quality from sugarcane juice (brix, juice purity, and fiber) were observed in this study, except for in sugar production (Figure 4). 

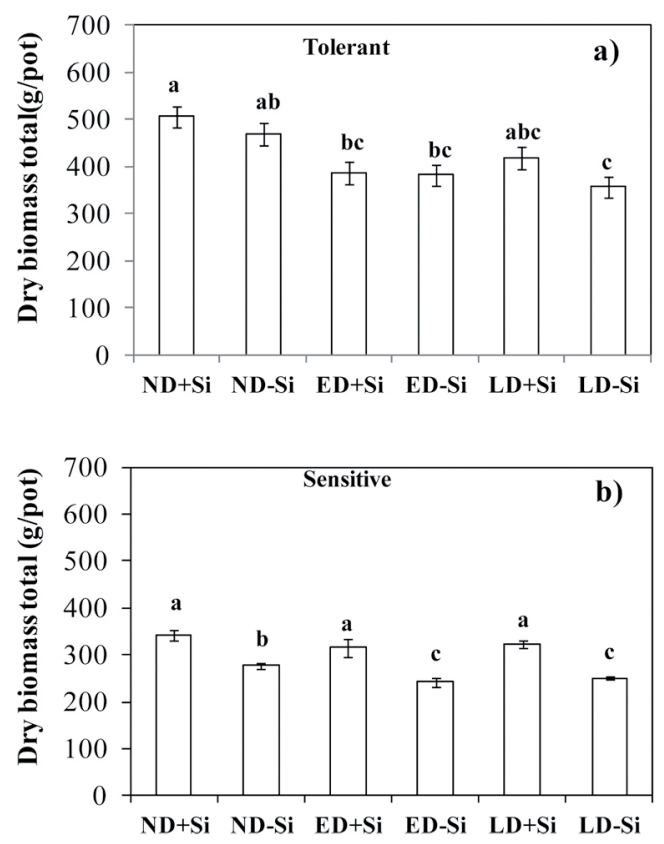

Figure 3. Above ground dry biomass (g) of droughttolerant (a) and drought-sensitive(b) sugarcane cultivars grown in sandy soil with $(+\mathrm{Si})$ and without $\mathrm{Si}$ (-Si) under non-deficit (ND), early (ED) and late water deficit (LD). Means followed by the same letter in the column do not differ by Tukey's test $(p<0.05)$. MSD0.05 $=110.32$ for the tolerance, and 34.85 for the sensitive. Standard error bars are included in all figures. $\mathrm{n}=4$ repetitions.

Brix, juice purity, and fiber were on average $18^{\circ}$, $>100 \%$ and $11 \%$, respectively, showing adequate timing for harvest in both experiments, according to Consecana (2006). However, the fiber content (insoluble material) was greater than that commonly found in the harvest of sugarcane crops because plant growth in pots can decrease the stalk:aboveground tissue ratio. Sugar production was higher in the drought-tolerant cultivar, and the highest values were obtained for $\mathrm{ND}+\mathrm{Si}$ and the lowest for $\mathrm{ED}-\mathrm{Si}$, and LD-Si (Figure 4a). In contrast, Si fertilization provided best and similar sugar yields (Figure 4b) for the drought-sensitive cultivar grown under continuous irrigation $(\mathrm{ND}+\mathrm{Si})$ and water deficit $(\mathrm{ED}+\mathrm{Si}$, $\mathrm{LD}+\mathrm{Si}$ ) (Figure 4b).
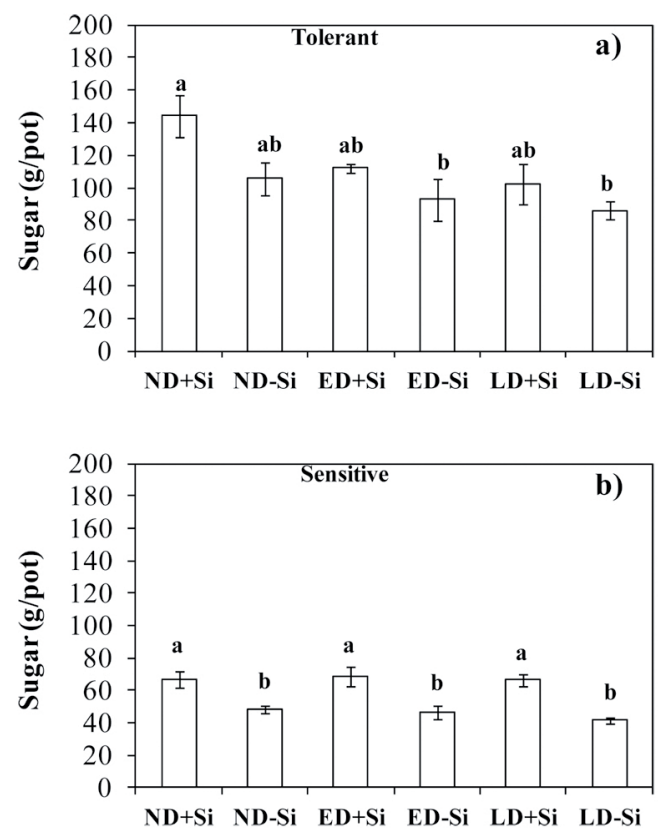

Figure 4. Sugar yield of drought-tolerant (a) and drought-sensitive (b) sugarcane cultivars grown in sandy soil with (+Si) and without $\mathrm{Si} \mathrm{(-Si)} \mathrm{under} \mathrm{non-}$ deficit (ND), early (ED) and late water deficit (LD). Means followed by the same letter in the column do not differ by Tukey's test $(p<0.05)$. MSD0.05 $=75.37$

\subsection{Silicon uptake by sugarcane}

The highest quantity of Si uptake by the aboveground tissues (leaves+stalk+straw) of the drought-tolerant cultivar was obtained with Si fertilization without and with water deficit treatments $(\mathrm{ND}+\mathrm{Si}, \mathrm{ED}+\mathrm{Si}$, and $\mathrm{LD}+\mathrm{Si}$ ), and the lowest values were obtained in the absence of this beneficial element (Figure 5). 
In contrast, a superior uptake of $\mathrm{Si}$ was observed in sugarcane grown with Si application under continuous irrigation $(\mathrm{ND}+\mathrm{Si})$, and the lowest was obtained without Si (ED-Si and LD-Si), in agreement with total dry biomass of the sensitive cultivar.
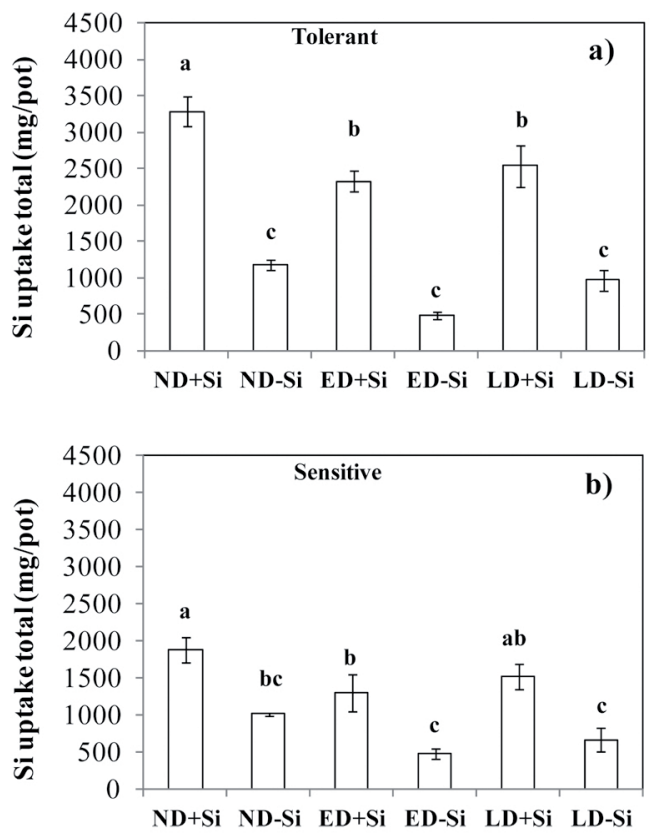

Figure 5. Silicon uptake (stalk+leaves + straw) of drought-tolerant (a) and drought-sensitive (b) sugarcane cultivars grown in sandy soil with $(+\mathrm{Si})$ and without $\mathrm{Si}(-\mathrm{Si})$ under non-deficit (ND), early (ED) and late water deficit (LD). Means followed by the same letter in the column do not differ by Tukey's test $(p<0.05)$. MSD0.05= 744.44 for the tolerance, and 570.83 for the sensitive. Standard error bars are included in all figures. $\mathrm{n}=4$ repetitions.

\subsection{Chemical characteristics and soluble silicon con- tent of the soil}

The soil samples exhibited low acidity $(\mathrm{pH}>7.0)$ and the $\mathrm{P}, \mathrm{Ca}$, and $\mathrm{Mg}$ contents were considered low (6-12 mg $\mathrm{dm}^{-3}$ of $\left.\mathrm{P}\right)$, high (> $7 \mathrm{mmolc} \mathrm{dm}^{-3} \mathrm{Ca}$ ), and medium (5-8 mmolc $\mathrm{dm}^{-3} \mathrm{Mg}$ ), respectively; and the base saturation (BS) was moderate (51-70\%) after both harvests (Table 2). These levels of soil fertility (acidity, $\mathrm{Ca}$ and $\mathrm{Mg}$ ) were adequate for sugarcane cultivation, according to the classification of Raij et al., (1997). Although sugarcane fertilization was performed according to Raij et al., (1997), low levels of $\mathrm{P}$ after harvest were found, which could be attributed to the uptake by the plant and the low initial levels of this type of soil.

The treatments did not affect $(p>0.05)$ the chemical characteristics of the soil samples that were collected from both experiments, except for the $\mathrm{P}$ and soluble Si contents (Table 2). The levels of phosphorus extracted by resin and soluble $\mathrm{Si}$ in acetic acid $\left(0.5 \mathrm{~mol} \mathrm{~L}^{-1}\right)$ and $\mathrm{CaCl}_{2}(0.01 \mathrm{~mol}$ $\mathrm{L}^{-1}$ ) were higher in all of the treatments that received $\mathrm{Si}$ fertilization, including those with water deficit (Table 2). The soluble Si contents (x) obtained by the extraction of acetic acid and $\mathrm{CaCl}_{2}$ were related with the $\mathrm{Si}$ uptake (y) by the whole plant (leaves+stalks+straw), and the availability of this element to the plant for each extractant solution was evaluated. The linear regression equations were significant $(p<0.05$, F test) for the soluble Si extracted by acetic acid from soil samples after harvesting the drought-tolerant cultivar $\left(\hat{\mathrm{y}}=635.130+21.763 \mathrm{x}, \mathrm{R}^{2}\right.$ $\left.=0.74^{*}, p<0.05\right)$ and the drought-sensitive cultivar $(\hat{\mathrm{y}}=$ $\left.587.68+9.968 \mathrm{x}, \mathrm{R}^{2}=0.64^{*}, p<0.05\right)$. They were also verified using $\mathrm{CaCl}_{2}$ from soil samples after the harvest of the drought-tolerant cultivar $\left(\hat{\mathrm{y}}=498.84+393.75 \mathrm{x}, \mathrm{R}^{2}\right.$ $\left.=0.49^{*}, p<0.05\right)$ and the drought-sensitive cultivar $(\hat{\mathrm{y}}=$ $\left.447.49+211.40 \times, \mathrm{R}^{2}=0.51^{*}, p<0.05\right)$. 
Table 2. Chemical attributes, soluble silicon in acetic acid $0.5 \mathrm{~mol} \mathrm{~L}^{-1}$ and $\mathrm{CaCl}_{2} 0.01 \mathrm{~mol} \mathrm{~L}^{-1}$ of soil samples collected after 11 months of two sugarcane cultivars grown in sandy soil with and without Si fertilization under non-deficit, and early and late water deficit.

\begin{tabular}{|c|c|c|c|c|c|c|c|c|c|c|c|c|c|c|c|c|}
\hline \multirow[t]{2}{*}{ Treatments } & \multicolumn{8}{|c|}{ Tolerant (RB86-7515) } & \multicolumn{8}{|c|}{ Sensitive (RB85-5536) } \\
\hline & $\mathrm{Sia}{ }^{1}$ & $\mathrm{Sic}^{2}$ & $\mathrm{pH}^{3}$ & $\mathrm{P}^{4}$ & $\mathrm{Ca}^{5}$ & $\mathrm{Mg}^{5}$ & $\mathrm{CEC}^{6}$ & $\mathrm{BS}^{7}$ & $\mathrm{Sia}^{1}$ & $\mathrm{Sic}^{2}$ & $\mathrm{pH}^{3}$ & $\mathrm{P}^{4}$ & $\mathrm{Ca}^{5}$ & $\mathrm{Mg}^{5}$ & $\mathrm{CEC}^{6}$ & $\mathrm{BS}^{7}$ \\
\hline $\mathrm{i}$ & $88.2 \mathrm{a}$ & $4.8 \mathrm{a}$ & $7.5 \mathrm{a}$ & $11.7 \mathrm{ab}$ & $20.2 \mathrm{a}$ & $5.0 \mathrm{a}$ & $39.2 \mathrm{a}$ & $66.2 \mathrm{a}$ & $100 . \mathrm{a}$ & $4.9 \mathrm{a}$ & $7.6 \mathrm{a}$ & $12.5 \mathrm{a}$ & 18.0ab & $4.5 \mathrm{ab}$ & $35.0 \mathrm{a}$ & $64.5 \mathrm{ab}$ \\
\hline & $12.5 \mathrm{~b}$ & $1.3 \mathrm{~b}$ & $7.4 \mathrm{a}$ & $5.5 \mathrm{~b}$ & $19.2 \mathrm{a}$ & $4.2 \mathrm{a}$ & & & & & $7.5 \mathrm{a}$ & 6. & & & & \\
\hline & $88.9 \mathrm{a}$ & $5.3 \mathrm{a}$ & $7.7 \mathrm{a}$ & $11.7 \mathrm{ab}$ & $19.0 \mathrm{a}$ & $4.5 \mathrm{a}$ & $37.0 \mathrm{a}$ & 66. & $9.6 \mathrm{a}$ & $5.1 \mathrm{a}$ & $7.6 \mathrm{a}$ & $12.0 \mathrm{a}$ & $17.7 \mathrm{ab}$ & $4.5 \mathrm{ab}$ & $34.7 \mathrm{ab}$ & $64.3 \mathrm{ab}$ \\
\hline 4-Ea & $13.5 \mathrm{~b}$ & $2.0 \mathrm{~b}$ & $7.4 \mathrm{a}$ & $5.5 \mathrm{~b}$ & $17.2 \mathrm{a}$ & $3.7 \mathrm{a}$ & $35.7 \mathrm{a}$ & 60. & b & $1.9 \mathrm{~b}$ & $7.5 \mathrm{a}$ & $6.2 \mathrm{~b}$ & $15.2 \mathrm{~b}$ & $3.0 \mathrm{~b}$ & 32 & $\mathrm{cc}$ \\
\hline & $102 \mathrm{a}$ & $4.3 \mathrm{a}$ & $7.7 \mathrm{a}$ & $18.5 \mathrm{a}$ & $17.5 \mathrm{a}$ & $4.5 \mathrm{a}$ & $35.2 \mathrm{a}$ & & $3.0 \mathrm{a}$ & $4.9 \mathrm{a}$ & $7.7 \mathrm{a}$ & $12.2 \mathrm{a}$ & 20 & 5. & & $68.5 \mathrm{a}$ \\
\hline & 6 & $2.0 \mathrm{~b}$ & $7.3 \mathrm{a}$ & $6.2 b$ & $18.2 \mathrm{a}$ & $3.7 \mathrm{a}$ & $37.0 \mathrm{a}$ & $62.0 \mathrm{a}$ & $13.4 \mathrm{~b}$ & $1.4 \mathrm{~b}$ & $7.3 \mathrm{a}$ & $6.0 \mathrm{~b}$ & $18.2 \mathrm{ab}$ & $3.5 \mathrm{~b}$ & $37.5 \mathrm{ab}$ & $60.7 \mathrm{bc}$ \\
\hline${ }^{8} \mathrm{MSD}^{(1}$ & 17.4 & 2.2 & 0.7 & 12.4 & 4.1 & 1.6 & 6.6 & 7.0 & 13.3 & 1.2 & 0.7 & 3.6 & 4.5 & 2.0 & 5.8 & 5.4 \\
\hline
\end{tabular}

${ }^{1} \mathrm{Sia}=\mathrm{Si}$ in acetic acid $0.5 \mathrm{~mol} \mathrm{~L}-1,{ }^{2} \mathrm{Sic}=\mathrm{Si}$ in $\mathrm{CaCl}_{2} 0,01 \mathrm{~mol} \mathrm{~L}-1 ;{ }^{3} \mathrm{pH} \mathrm{CaCl} ;{ }^{4} \mathrm{P}=$ anion resin exchangeable; ${ }^{5} \mathrm{Ammonium}$ acetate method; ${ }^{6}$ Cation exchange capacity; ${ }^{7}$ Base saturation; ${ }^{8} \mathrm{MSD}=$ minimum significant difference. $* *$ Means followed by the same letter in the column do not differ based on a Tukey's test $(p<0.05)$.

\section{Discussion}

Silicate fertilization increased the soluble Si concentration in the soils, which resulted in an increased Si uptake, dry biomass, and sugar and stalk yield of sugarcane grown under continuous irrigation and water deficit imposed in both phenological stages. Althought positive responses of silicate fertilization were observed for both cultivars, Si provided similar sugar and stalk yield for water deficit treatments $(\mathrm{ED}+\mathrm{Si}, \mathrm{LD}+\mathrm{Si})$ and continuous irrigation $(\mathrm{ND}+\mathrm{Si})$ for drought-sensitive cultivar. These results demonstrated that Si was useful to recovery of droughtsensitive sugarcane cultivars after both water deficit periods, which did not show yet for sugarcane crop.

The initial levels of $\mathrm{Si}$ in the soil $\left(0-5 \mathrm{mg} \mathrm{kg}^{-1} \mathrm{Si}, 0.01\right.$ $\mathrm{Mol} \mathrm{L}{ }^{-1} \mathrm{CaCl}_{2} ;<15 \mathrm{mg} \mathrm{kg}^{-1} \mathrm{Si}, 0.5 \mathrm{~mol} \mathrm{~L}^{-1}$ acetic acid) were considered low (Berthelsen et al., 2001; Mc Cray and Ji, 2012) as a consequence of the sandy texture (Camargo et al., 2013). Si fertilization promoted sharp increases in the Si content in the soil extracted by both extractors. Although these values are not considered sufficient $\left(>20 \mathrm{mg} \mathrm{kg}^{-1} \mathrm{Si}\right.$ extracted by $\mathrm{CaCl}_{2}$ $0.01 \mathrm{~mol} \mathrm{~L}^{-1}$ ) for sugarcane according to Berthelsen et al., (2001), positive results in sugarcane yield have already been obtained in soils with similar Si contents (Mc Cray and Ji, 2012; Camargo et al., 2013), in agreement with the results of this study.

Although acetic acid has greater power to extract soluble $\mathrm{Si}$ from the soil than does $\mathrm{CaCl}_{2}$, it showed the correlation with $\mathrm{Si}$ uptake (leaves+stalks+straw) due to its high determination coefficient $\left(\mathrm{R}^{2}\right)$ as reported in other studies (Camargo et al., 2013; Camargo et $a l ., 2014)$. When silicate is used as a Si source, similar values of $\mathrm{pH}, \mathrm{Ca}$, and $\mathrm{Mg}$ are necessary in all treatments to observe only the effects of increasing the $\mathrm{Si}$ availability in the soil and $\mathrm{Si}$ application, as in this study. Moreover, the absence of differences in these values among treatments confirmed that the results obtained were due to increases in the soluble $\mathrm{Si}$ in soil and its uptake by plant. This increase in the P content in soil with Si addition could be related to the exchange of Si by $\mathrm{P}$ because both elements occupy the same adsorption sites, but there is no effect on $\mathrm{P}$ uptake by plants (data not shown).

The stalk diameter and plant height are important attributes for determining the potential of sugarcane yield (Dinardo-Miranda et al., 2010; Silva et al., 2008). 
The negative drought effects on these attributes have already been observed in some genotypes of sugarcane cultivars (Silva and Costa 2004; Silva et al., 2008; Machado et al., 2009). In this study, water deficit reduced these attributes only for the sensitive cultivar and when there was no application of Si to the soil. On the contrary, no reduction in the stalk diameter or plant height with Si fertilization was observed, and treatments with irrigation $(\mathrm{ND}+\mathrm{Si})$ and under deficit $(\mathrm{ED}+\mathrm{Si}, \mathrm{LD}+\mathrm{Si})$ had similar and the highest values. Moreover, the plant height, and stalk length were not different among treatments, unlike those observed in some studies that were conducted under field conditions (Inman-Bamber and Smith, 2005; Silva and Costa, 2004) and in pots (Machado et al., 2009; Carlin and Santos, 2009). This can be explained because the intensity of the water deficit was moderate $(55 \%$ field capacity) (Carlin and Santos, 2009; Oliveira et $a l ., 2010)$ and longer duration (60 days), unlike that of other studies using severe water deficit (20 to $40 \%$ field capacity) to assess the immediate effects (Carlin and Santos, 2009, Oliveira et al., 2010; Boaretto et al., 2014) or the recovery of the plant after stress (Machado et al., 2009).

Sugarcane stalk is considered the main component in this crop (Dinardo-Miranda et al., 2010) because sugar and ethanol are obtained by processing the juice extracted from the stalk. The decreased stalk yield grown under water deficit (Machado et al., 2009; Inman-Bamber and Smith, 2005; Ramesh, 2000; Silva and Costa, 2004) was also verified in this study. Water deficit has reduced the sugar yield, which has not been evaluated in most studies of sugarcane and abiotic stress conducted in pots, with the exception of studies of salinity and Si (Ashram et al., 2010). The effects of Si fertilization were markedly positive on the alleviation of water deficit in the sensitive cultivar, resulting in a similar stalk and sugar yield in the following treatments: $\mathrm{Si}$ and continuous irrigation $(\mathrm{ND}+\mathrm{Si})$ and early and late deficit (ED+Si and $\mathrm{LD}+\mathrm{Si})$ (Figures $2 \mathrm{~b}, 4 \mathrm{~b})$. For the tolerant variety, a decreased stalk and sugar yield was observed only in the treatments under water deficit without $\mathrm{Si}$ (ED-Si and LD-Si), which were not different from ND-Si, ED+Si and LD+Si.

Si fertilization increased the stalk and sugar yield of sensitive sugarcane cultivars, even when grown under water deficit conditions, which could be useful for planting these cultivars in soils subject to drought. Although tolerant cultivars are indicated for conditions of water deficit (Dinardo-Miranda et al., 2010), sensitive cultivars are still being used in sugarcane fields due to their higher sugar yield in response to fertilization under adequate conditions of soil and water availability and variability in planting and harvesting seasons compared to some tolerant cultivars (Dinardo-Miranda et al., 2010; Gava et al., 2011). On the other hand, for the tolerant cultivar, just the water supply, even without $\mathrm{Si}$ application (ND-Si), showed best increase in the stalk and sugar yield compared to both water deficit treatments with $\mathrm{Si}$ application $(\mathrm{ED}+\mathrm{Si}$ and $\mathrm{LD}+\mathrm{Si}$ ). However, $\mathrm{Si}$ is also important for tolerant cultivars because irrigation is not available in these areas and/or is costly; silicate fertilization is one alternative to increase the stalk and sugar yield, as shown in the ED-Si and LD-Si treatments.

The positive effects of $\mathrm{Si}$ on the dry biomass and sugar and stalk yield are in agreement to increase of Si uptake by above-ground biomass after two water deficit periods, whose values were inferior when this beneficial element was not applied in soil for both cultivars (Figure 5). Although water deficit commonly reduces dry biomass yield, the Si plays a important role in osmotic adjustment, reducing the water loss and increasing biomass yield, as already reported to wheat (Gong et al., 2005) and sorghum (Hattori et al., 2005). Sonode et al., (2011) have also reported the alleviation of Si fertilization for sorghum grown under water deficit due to osmotic adjustment and 
consequent increase on water uptake by roots and dry weight. In addition, studies have already shown the positive effect of Si on antioxidant enzymes of plants under water deficit, providing maintenance of growing even in these stressful conditions (Gong et al., 2005).

The water deficit periods used in this study were chosen due to dry season occurrence (May-August) in the South Central region of Brazil, which is the most representative area of sugarcane cropping (Conab, 2016). The periods were also chosen because the dry season coincides with the most prejudicial phases for the growth of sugarcane (tillering and early grand growth) for sugarcane planting in January. In addition, some producers have used irrigation during the dry season, but information is still scarce about the positive effects of this practice (Gava et al., 2011). Considering the common higher temperatures and number of hours of sunlight after September in this region, it is possible that late water deficit (July-September) had caused a higher prejudice in stalk yield compared to early water deficit (May-July). However, early water deficit (120-150 days) and late water deficit (150-210 days) without $\mathrm{Si}(\mathrm{ED}+\mathrm{Si}$ and $\mathrm{LD}+\mathrm{Si})$ did not show differences in the stalk, sugar and dry biomass (Figure 2,3,4) at harvest 330 days after transplanting. The negative impact on dry biomass of drought-sensitive cultivar (IACSP 96-2042) caused by water deficit imposed during 73 and 114 days have also observed by Machado et al., (2009). In addition, dry biomass reduction in the range of 67$80 \%$ have also observed in sugarcane grown under water deficit in pots (22 L) during 84 days (Pincelli and Silva, 2012). More recently, Ecco et al., (2014) have also found $78-83 \%$ of decrease on dry biomass of the same cultivars evaluated in this study when they grown under intense deficit (20-40\% field capacity) during 95 days.

Despite of deleterious effects of drought observed, $\mathrm{Si}$ provided best recovery of sugarcane at harvest after both periods (early and late) of water deficit. It was markedly reduced the sugar and stalk yield, and dry biomass of above-ground when water deficit was imposed (ED-
Si, LD-Si) compared to superior values (Figures 2, 3, 4) obtained for the same conditions with Si fertilization $(\mathrm{ED}+\mathrm{Si}, \mathrm{LD}+\mathrm{Si})$. The Si fertilization have also provided increase of dry biomass of rice (Sonodi et $\mathrm{al}, 2011)$ and forage grass grown under water deficit (Eneji et al., 2008) and dry biomass of rice (Mahdieh et al., 2015) and sugarcane grown under salinity and Si (Ashraf et al., 2010).

Finally, the results observed in this study confirm the alleviation of deleterious effects of water deficit with Si fertilization in both drought-sensitive and droughttolerant cultivars. Future studies under field conditions and with more sugarcane cultivars are necessary to provide more information about the effects of $\mathrm{Si}$ application after periods of water deficit on the harvest of sugarcane. This information will improve the management of cultivars and water in this crop.

\section{Conclusions}

Silicon fertilization provided best recovery of sugarcane (superior sugar, stalk yield, and dry biomass of above-ground) after early and late water deficit compared to its absence for RB86-7515 (drought tolerant) and RB85-5536 (drought sensitive) cultivars. For RB85-5536, Si fertilization propitiated similar recovery for water deficit treatments and continuous irrigation. No differences were observed between periods of water deficit. Therefore, Si fertilization at planting should be considered another tool for reducing the damage caused by water deficit in sugarcane.

\section{Acknowledgments}

The authors would like to thank Sao Paulo State Research Foundation (FAPESP) for financial support of the project 2013/04144-7 and Federal University of Sao Carlos (UFSCAR/CCA) for providing stalks of sugarcane cultivars. 


\section{References}

Abbas, S.R., Ahmad, S.D., Sabir, S.M., Shah, A.H. 2014. Detection of drought tolerant sugarcane genotypes (Saccharum officinarum) using lipid peroxidation, antioxidant activity, glycine-betaine and proline contents. J. Soil Sci. Plant Nutr. 14, 233-243.

Ashraf, M., Rahmatullah, R., Afzal, M., Ahmed, R., Mujeeb, F., Sarwar, A., Ali, L. 2010. Alleviation of detrimental effects of $\mathrm{NaCl}$ by silicon nutrition in salt-sensitive and salt-tolerant genotypes of sugarcane (Saccharum officinarum L.). Plant Soil. 326, 381-391.

Barbosa, F.S., Coelho, R.D., Maschio, R., Lima, J.G.S., Silva, E.M. 2014. Drought resistance of sugar-cane for different levels of water availability water in the soil. J. Braz. Assoc. Agric. Eng. 34, 203-210.

Berthelsen, S., Hurney, A., Noble, A., Rudd, A., Garside, A.L., Henderson, A. 2001. An assessment of current silicon status of sugar cane production soils from Tully to Mossman. Proc. Aust. Sugar Cane Technol. 23, 289-296.

Boaretto, L.F., Carvalho, G., Borgo, L., Creste, L., Landell, M.G.A., Mazzafera, P., Azevedo, R.A. 2014. Water stress reveals differential antioxidant responses of tolerant and non-tolerant sugarcane genotypes. Plant Physiol. Biochem. 74, 165-175.

Camargo, M.S., Korndörfer, G.H., Foltran, D.E., Henrique, C.M., Rossetto, R. 2010. Silicon uptake, yield and Diatraea saccharalis incidence in sugarcane cultivars. Bragantia. 69, 937-944.

Camargo, M.S., Korndörfer, G.H., Wyler, P. 2014. Silicate fertilization of sugarcane cultivated in tropical soils. Field Crops Res. 167, 64-75.

Camargo, M.S., Amorim, L., Gomes Júnior, A.R. 2013. Silicon fertilization decreases brown rust incidence in sugarcane. Crop Prot. 53, 72-79.
Carlin, S.D., Santos, D.M.M. 2009. Physiological indicators of the interaction between water deficit and soil acidity in sugarcane. Pesq. Agropec. Bras. 44, 1106-1113.

Companhia Nacional de Abastecimento (CONAB). Web sugarcane service. http:// www.conab.gov.br/OlalaCMS/uploads/arquivos/13_08_08_09_39_29_boletim_cana_portugues_-_abril_2013_1o_lev.pdf

Conselho dos Produtores de Cana-de-Açúcar, Açúcar e Álcool do Estado de São Paulo (CONSECANA) 2006. Instructions Manual. CONSECANA, Piracicaba

Dinardo-Miranda, L.L., Vasconcelos, A.C.M., Landell, M.G.A. 2010. Cana-de-açúcar. Instituto Agronômico de Campinas, Campinas.

Ecco, M., Santiago, E.F., Lima, P.R. 2014. Biometric answers in young plants of cane sugar under the water stress and the aluminum. Comunicata Scientiae. 5, 59-67.

Elliott, C.L., Snyder, G.H. 1991. Autoclave-induced digestion for the colometric determination of silicon in rice straw. J. Agric.Food Chem. 39, 1118-1119.

Epstein, E. 2009. Silicon: its manifold roles in plants. Ann. Appl. Biol. 155, 155-160.

Eneji, A.E., Inanaga, S., Muranaka, S., Li, J., Hattori, T., An, P., Tsuji, W. 2008. Growth and nutrient use in four grasses under drought stress as mediated by silicon fertilisers. J. Plant Nutr. 1, 355-365.

Gava, G.J.C., Silva, M.A., Silva, R.C., Jeronimo, E.M., Cruz, J.C.S., Kolln, O.T. 2011. Productivity of three sugarcane cultivars under dry and drip irrigated management. R. Bras. Eng. Agric. Amb. 15, 250-255.

Gentile, A., Ferreira, T.H., Mattos, R.S., Dias, L.I. Hoshino, A.A., Carneiro,M.S., Souza, G.M., Calsa, T., Nogueira, R.M., Endres, L., Menossi, 
M. 2013. Effects of drought on the microtranscriptome of field-grown sugarcane plants. Planta. 237, 783-798.

Gong, H., Zhu, X., Chen, K., Wang, S., Zhang, C. 2005. Silicon alleviates oxidative damage of wheat plants in pots under drought. Plant Sci. 169, 313-321.

Hattori, T., Inanaga, S., Araki, H., Morita, S., Luxová, M., Lux, A. 2005. Application of silicon enhanced drought tolerance in Sorghum bicolor. Physiol. Plantarum. 123, 459-466

Inman-Bamber, N.G., Smith, D.M. 2005. Water relations in sugarcane and response to water deficits. Field Crops Res. 92, 185-202.

Keeping, M.G., Meyer, J.H., Sewpersad, C. 2013. Soil silicon amendments increase resistance of sugarcane to stalk borer Eldana saccharina Walker (Lepidoptera: Pyralidae) under field conditions. Plant Soil. 363, 297-318.

Korndörfer, G.H., Coelho, N.M., Snyder, G.H., Mizutani, C.T. 1999. An evaluation of soil extractants for silicon availability in upland rice. Braz. J. Soil Sci. 23, 101-106.

Machado, R.S., Ribeiro, R.V., Marchiori, P.E.R., Machado, D.F.S.P., Machado, E.C., Landell, M.G.A. 2009. Respostas biométricas e fisiológicas ao déficit hídrico em cana-de-açúcar em diferentes fases fenológicas. Pesq. Agropec. Bras. 44, 1575-1582.

Mahdieh, M., Habibollahi, N., Amirjani, M.R., Abnosi, M. H., Ghorbanpour, M. 2015. Exogenous silicon nutrition ameliorates salt-induced stress by improving growth and efficiency of PSII in Oryza sativa L. cultivars. J. Soil Sci. Plant Nutr. 15, 1050-1060.

McCray, J.M., Shangning, Ji. 2012. Calibration of sugarcane response to calcium silicate on Florida Histosols. J. Plant Nutr. 35, 1192-1209.
Oliveira, C.M.R., Passos, R., Andrade, F.V., Reis, E.D., Sturm, G.M., Souza, R.B. 2010. Corretivos da acidez do solo e níveis de umidade no desenvolvimento da cana-de-açúcar. R. Bras. Ci. Agrárias. 5, 25-31.

Oliveira, E.C.A., Freire, F.J., Oliveira, A.C., Neto, D.E.S., Rocha, A.T., Carvalho, L.A. 2011. Productivity, water use efficiency, and technological quality of sugarcane subjected to different water regimes. Pesq. Agropec. Bras. 46, 617-625.

Pincelli, R.P., Silva, M.A. 2012. Leaf morphological changes in sugarcane cultivars in response to water deficit. Biosci. J. 28, 546-556.

Raij, B. van, Cantarella, H., Quaggio, J.A., Furlani, A.M.C. 1997. Fertilization and liming to São Paulo state. Instituto Agronômico de Campinas, Campinas.

Rede Interuniversitária para Desenvolvimento do Setor Sucroalcooleiro (RIDESA). 2011. Sugarcane cultivars. Revista Censo Varietal. (in Portuguese) http://pmgca.dbv.cca.ufscar.br/htm/downloads.php (accessed 07.07.2016).

Ramesh, P. 2000 Effect of different levels of drought during the formative phase on growth parameters and its relationship with dry matter accumulation in sugarcane. J. Agron. Crop Sci. 185, 83-89.

Silva, A.L.C., Costa, W.A.JM. 2004. Varietal variation in growth, physiology and yield of sugarcane under two contrasting water regimes. Trop. Agric. Res. 16, 1-12.

Silva, M.A., Soares, R.A.B., Landell, M.G.A., Campana, M.P. 2008. Agronomic performance of sugarcane families in response to water stress. Bragantia. 67, 656-661.

Sonobe, K., Hattori, T., An,P., Tsuji, W., Eneji,A.E., Kobayashi,S., Kawamura, Y., Tanaka,K., Inanaga, S. 2011. Effect of silicon application on sorghum root responses to water stress. J. Plant Nutr. 34, 71-82. 